Canadian

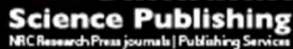

Canadian Geotechnical Journal Revue canadienne de géotechnique

\title{
Erosion monitoring during core overtopping using a laboratory model with digital image correlation and X-ray microcomputed tomography
}

\begin{tabular}{|r|l|}
\hline Journal: & Canadian Geotechnical Journal \\
\hline Manuscript ID & cgj-2016-0684.R1 \\
\hline Manuscript Type: & Article \\
\hline Date Submitted by the Author: & 27-Jun-2017 \\
\hline Complete List of Authors: & $\begin{array}{l}\text { Dumberry, Kevin; École de technologie supérieure, } \\
\text { Duhaime, François; Ecole de technologie superieure, Construction } \\
\text { Engineering } \\
\text { Éthier, Yannic; École de technologie supérieure, Génie de la construction }\end{array}$ \\
\hline Keyword: & $\begin{array}{l}\text { core overtopping, contact erosion, embankment dams, digital image } \\
\text { correlation, microcomputed tomography }\end{array}$ \\
\hline \multicolumn{2}{|c}{} \\
\hline
\end{tabular}


3 Erosion monitoring during core overtopping using a laboratory model with

${ }^{1}$ Department of Construction Engineering, École de technologie supérieure, 1100, rue Notre-Dame Ouest, Montréal, Québec, Canada, H3C 1K3 


\section{Abstract}

21 Core overtopping in embankment dams is an important phenomenon that may lead to contact erosion 22 along the core/filter interface. This paper presents new experimental results regarding erosion 23 mechanisms at the core/filter interface during core overtopping. The experimental results were obtained 24 using a reduced-scale model with a variable upstream water level. Digital image correlation (DIC), 25 microcomputed tomography $(\mu \mathrm{CT})$ and sediment collection at the outlet were used to quantify erosion. 26 Four experimental runs were conducted with a till core and different filters. Only one of the four filters 27 satisfied the filter criteria that were applied. No contact erosion occurred during this test. For filters that 28 did not respect the filter criteria, piping occurred within the core along the downstream slope when the 29 water level reached the top of the core. As a result of the self-healing process within the core material, the 30 erosion rate decayed with time as the hydraulic gradient increased. Results for DIC mainly reflected 31 settlements within the filter due to erosion and a soil arching effect. The magnitude of the displacement 32 vector obtained with DIC is directly proportional to the volume of till eroded. $\mu$ CT showed that contact 33 erosion occurred continuously.

34 Keywords: core overtopping, contact erosion, embankment dams, digital image correlation, 35 microcomputed tomography 


\section{Résumé}

38 Pour les barrages en remblai zonés, le franchissement de noyau est un problème important qui peut 39 provoquer une érosion de contact le long de l'interface noyau/filtre. Cet article présente de nouveaux 40 résultats expérimentaux sur les mécanismes d'érosion à l'interface noyau/filtre durant le franchissement

41 de noyau. Les résultats expérimentaux ont été obtenus à partir d'un modèle à échelle réduite dont le 42 niveau d'eau amont est variable. La corrélation d'images numériques (DIC), la microtomodensitométrie à 43 rayons $\mathrm{X}(\mu \mathrm{CT})$ et la collecte de sédiments en aval du montage ont permis de quantifier l'érosion. Quatre 44 essais ont été effectués avec un noyau en till et différents matériaux filtrants. Seulement un des filtres 45 respectait les critères de filtre qui ont été utilisés. Aucune érosion de contact ne s'est produite pour ce test. 46 Pour les filtres qui ne respectaient pas les critères de filtre, un phénomène d'érosion régressive (renard 47 hydraulique) est apparu le long de la pente aval du noyau lorsque le niveau d'eau a atteint le sommet du 48 noyau. Le taux d'érosion a diminué dans le temps à mesure que le gradient hydraulique augmentait, dû à 49 un phénomène d'autoréparation du noyau. La DIC a permis de mettre en évidence les tassements 50 verticaux dans le filtre ainsi qu'un effet d'arche. Le déplacement vectoriel mesuré par la DIC est 51 directement proportionnel au volume de till érodé. La $\mu \mathrm{CT}$ a démontré que l'érosion de contact se produit 52 en continu.

53 Mots clés : franchissement de noyau, érosion de contact, barrages en remblai, corrélation d'images 54 numériques, microtomodensitométrie 


\section{List of symbols}

$57 \quad A \quad$ Modified fines content

$58 \quad C_{\mathrm{u}} \quad$ Coefficient of uniformity

$59 \quad D_{10} \quad$ Effective diameter

$60 \quad D_{15} \quad$ Diameter of filter particles corresponding to $15 \%$ passing by mass

$61 \quad d_{85} \quad$ Diameter of core particles corresponding to $85 \%$ passing by mass

$62 e \quad$ Void ratio

$63 e_{\min } \quad$ Minimum-index void ratio

$64 e_{\max } \quad$ Maximum-index void ratio

$65 \quad G_{\mathrm{s}} \quad$ Specific gravity of solids

$66 \quad I_{\mathrm{d}} \quad$ Relative density index

$67 \quad R C \quad$ Relative compaction

$68 w \quad$ Water content

$69 w_{\mathrm{opt}} \quad$ Optimum water content

$70 \quad \rho_{\mathrm{d}} \quad$ Dry density

$71 \rho_{\mathrm{d} \max } \quad$ Maximum dry density

$72 \quad \rho_{\mathrm{d} \min } \quad$ Minimum dry density

73 


\section{$74 \quad$ Introduction}

The core/filter interface of an embankment dam can be vulnerable to erosion if the upstream water level rises over the top of the core (Figure 1). In the long term, instabilities can be generated and filter effectiveness within the dam reduced. This phenomenon, called core overtopping, may be a consequence of heavy precipitation, climate change or inadequate spillway capacity. Due to recent improvements in the analysis of extreme flood events, and better precipitation and watershed information, it has been inferred that several thousand dams in the United States alone do not have sufficient spillway capacity to accommodate the appropriate design floods (FEMA 2014).

Dam failure can have severe economic, social and environmental consequences. Since internal erosion is recognized as an important cause of dam failure (Foster et al. 2000), the ability to predict and understand erosion processes for different parts of a dam is fundamental. In the complex setting of an embankment dam crest, previous studies suggest that erosion is mostly associated with: 1) large hydraulic gradients and flow velocities, especially at the downstream edge of the core/filter interface (Wörman and Skoglund 1992) and in the unsaturated portion of the core and filter (Zhang and Chen 2006); 2) within zones of low effective stress due to soil arching (Fell et al. 2015). Internal erosion is also associated with materials that are internally unstable (broadly or gap-graded grain size distributions) or combinations of materials that fail to satisfy the filter criteria (e.g., Sherard et al. 1984; Indraratna et al. 2011). Currently, the design of filters and the prediction of their long-term behaviour are mainly assessed by empirical relationships based on grain size distributions and judgment (Fell et al. 2015). These criteria have evolved through time. As a result, older structures do not necessarily reflect current practices for filter design and could be susceptible to erosion.

A limited number of experimental studies have addressed the phenomenon of core overtopping. Some researchers focused on the horizontal interface between a base material and a coarse material under tangential flow conditions (Wörman 1996; Guidoux et al. 2010; Dionne and Konrad 2015), while others considered more realistic geometric configurations and hydraulic boundaries (Wörman and Olafsdottir 
1992; Wörman and Skoglund 1992; Seo et al. 2006; Maknoon and Mahdi 2010). Most experimental studies have shown that fulfilling the filter criteria prevents the propagation of contact erosion during core overtopping. Otherwise, contact erosion is initiated at the downstream edge of the core/filter interface, where local hydraulic gradients are higher. Since these local hydraulic gradients do not increase significantly with the rise of the upstream water level, the progression of contact erosion is not influenced by an increasing water level (Wörman and Olafsdottir 1992).

Empirical criteria based solely on grain size distributions are not sufficient to model the progression of erosion. Internal erosion depends on pore and grain geometries, effective stress, porosity, water velocity and degree of saturation. The interplay between these parameters has also been demonstrated for other erosion phenomena, such as piping, where a granular material is eroded through a conduit (Richards and Reddy 2012; Van Beek et al. 2015), and bridge scour (Briaud 2008). For instance, Richards and Reddy (2012) observed that seepage velocities between 0.02 and $1.2 \mathrm{~cm} / \mathrm{s}$ were needed to initiate piping in different soils depending on the effective stress, the void ratio and the grain size distribution. Low velocities were sufficient to initiate internal erosion (suffusion) for soils with nonplastic fines. For bridge scour, Briaud (2008) showed that a velocity in excess of $10 \mathrm{~cm} / \mathrm{s}$ is needed to erode fine sand.

The parameters that control erosion depend on both macro- and microscale phenomena (Pirnia et al. 2016). State-of-the-art experimental and numerical methods, such as X-ray microcomputed tomography $(\mu \mathrm{CT})$, digital image correlation (DIC) and discrete element modelling (DEM), now allow the microscale behaviour of soil to be studied. However, the progression of internal erosion at the pore scale has not been studied thoroughly (Binner et al. 2010; Beguin et al. 2013; Takano et al. 2015). Most studies used $\mu \mathrm{CT}$ to evaluate the properties of uniform granular specimens, such as bulk density, water content and porosity (Tollner and Verma 1989; Kim et al. 2013, Takano et al. 2015). DIC has been predominantly used to investigate local strains in granular materials under loading (White et al. 2003; Pan et al. 2007; Boccalini et al. 2015). 
There is currently a lack of knowledge regarding the progression of contact erosion for complex geometries, flow conditions influenced by gravity, upstream hydraulic boundaries that vary in the shortterm and broadly graded materials. Indeed, a review of the literature indicates that there is a need for

127 experimental data that are more consistent with actual field conditions. Moreover, few attempts have been

128 made to examine contact erosion with DIC and $\mu \mathrm{CT}$. This study aims at evaluating the relationship

129 between the progression of erosion during core overtopping and filter criteria. It is inferred that a

130 laboratory model more representative of actual field conditions along with DIC and $\mu$ CT should provide

131 insight on the erosion mechanisms at the local scale during core overtopping. The experimental setup

132 allows the placement of broadly graded materials with a representative geometry and the application of

133 2D hydraulic boundary conditions. This paper describes the physical model developed for this study.

134 Important DIC and $\mu \mathrm{CT}$ concepts are also defined. Experimental results are presented, along with a 135 discussion that puts the emphasis on the conditions leading to erosion and the potential applications of 136 DIC and $\mu \mathrm{CT}$ in the study of internal and contact erosion.

\section{Methodology}

\section{Experimental Setup}

The experimental setup used in this study is presented in Figure 2. The basin is made of 19-mm-

142 upstream water reservoir connected to the main section where the till and filter materials are placed. The

143 main section is $1.0 \mathrm{~m}$ long, $0.5 \mathrm{~m}$ wide and $0.6 \mathrm{~m}$ high, with a total volume of $0.3 \mathrm{~m}^{3}$. The model width

144 was chosen to have a ratio of at least 1:8 between the maximum particle size of the tested materials and

145 the basin dimensions (Figure 2a). This requirement limits the influence of preferential flow, erosion and

146 segregation along the walls of the test setup (Chapuis 2012). In accordance with this maximum ratio, the

147 maximum particle size was $56 \mathrm{~mm}$. 
The physical model represents the top of an embankment dam core. The core material forms a 149 trapezoidal prism with a height of $0.25 \mathrm{~m}$, a base of $0.80 \mathrm{~m}$, and $5 \mathrm{~V}: 1 \mathrm{H}$ side slopes (Figure $2 \mathrm{a}$ ). These 150 proportions are based on typical crest dimensions for the core of earthfill dams in eastern Canada 151 (SEBJ 1987). Different filter materials were placed around the core for each test. As the objective of this 152 project was to make a preliminary survey of erosion mechanisms during core overtopping, effective stress 153 conditions of actual dams were not reproduced: effective stresses were lower in the experimental model 154 than in actual dams. Moreover, overall hydraulic gradients in the filters were higher than those observed 155 in actual dam configurations where the width of the top of the core is larger (SEBJ 1987).

A plastic sheet with 14-mm holes and a nylon mesh with 1-mm openings allowed water to flow 157 into the soil from the upstream reservoir (Figure 2a). The latter included a series of overflow drains to 158 allow the upstream hydraulic head to be changed during core overtopping. A 5-mm-wide downstream 159 outlet slot permitted both water and eroded particles to be collected in a sedimentation column. The 160 overflow drains of the upstream reservoir and the sedimentation column flowed into a water tank located 161 underneath the basin (Figure 2b). The water tank also collected fine particles not intercepted by the 162 sedimentation column. Seepage was driven by gravity. The system was open as water at the outlet was 163 not reused.

Tap water was used for this study. Water temperature was recorded during each test but was not 165 controlled. Water temperatures for Tests 3,4 and $4 \mathrm{a}$ were respectively 22,23 and $15^{\circ} \mathrm{C}$. Because Tests 1 166 and 2 were conducted during winter, the water temperatures were significantly lower (respectively 3 and $\left.1676{ }^{\circ} \mathrm{C}\right)$. Because of the large volume of water involved with each test, the water was not deaired before 168 entering the test set-up. Since unsaturated flow is acknowledged in real dams (Saint-Arnaud 1995), it does 169 not appear unrealistic to use regular tap water in the test set-up.

Two high-resolution colour cameras with softbox lighting were mounted in front of the basin

171 (Figure 2c). The first camera recorded one image per second of the whole test setup with an 8-mm 
172 objective. The second camera recorded three images per second of the downstream part of the core/filter 173 interface with a 16-mm objective. This region of interest was chosen because erosion was initiated at the 174 downstream edge of the core in previous experiments (Wörman and Skoglund 1992; Javadi and Mahdi 175 2014). To prevent scratches, a transparent plastic film was applied on the inside of the sidewall that was 176 filmed. Hydraulic head and suction were also measured in the core using six open piezometers and three 177 pressure transducers with porous stones. Hydraulic head values are not presented herein, but have been 178 discussed at length in Dumberry (2017). as filters. The well graded sand was representative of materials that have been used as filters for some 184 dams in northern Quebec (Figure 3). Filter criteria from Fell et al. (2015) were used for the purpose of 185 this study (see Table 1). Based on these criteria, the minimal value of $D_{15}$ for the filter, the diameter of filter particles corresponding to $15 \%$ passing by mass, is determined by both the $d_{85}$, the diameter of core particles corresponding to $85 \%$ passing by mass, and the fines content, $A$, of the core material. In accordance with Table 1, filters must have a $D_{15} \leq 0.7 \mathrm{~mm}$ to fulfill the filter criteria applicable to embankment dams with broadly graded cores. As shown in Table 2, the three uniform gravel materials did not fulfill the filter criterion, while the $2 \mathrm{C}$ material did. One material had a $D_{15}$ value relatively close

191 to the filter criteria, while the two others were coarser. Filters G1, G2 and G3 were washed to remove 192 fines prior to tests. Table 3 presents the effective diameter, $D_{10}$, the coefficient of uniformity, $C_{\mathrm{u}}$, the 193 relative density of solids $D_{\mathrm{R}}$, the minimum and maximum values of the void ratio, $e$, the minimum and 194 maximum values of the dry density, $\rho_{\mathrm{d}}$, and the optimum water content, $w_{\mathrm{opt}}$, of the materials used in this 195 study. These parameters were determined using applicable ASTM standards (i.e. ASTM 2007; ASTM 196 2012; ASTM 2014a; ASTM 2014b). As shown on Figure 3, the minimum particle size for materials G3 
and $2 \mathrm{C}$ was lower than the width of the outlet slot. To prevent piping of the filter material through the slot

198 during these tests, a fine layer of material G2 was placed along the width of the outlet slot.

199 The behaviour of the core material may influence the dam performance. In northern Quebec, glacial till 200 deposits are generally characterized by a low plasticity index, a low compressibility and a high shear 201 strength (Boulton 1977). They are well or broadly graded materials, which can be susceptible to 202 suffossion and segregation (Sherard et al. 1984; Milligan 2003). However, their potentially unstable 203 behaviour tends to be rectified by a self-healing process, as the fine particle that are eroded upstream 204 gradually fill the pore network downstream, thus limiting the progression of erosion (Fell and Fry 2007). 205 Lafleur et al. (1999) demonstrated that glacial tills from northern Quebec should be stable with respect to 206 suffossion for a fines content higher than $12 \%$, which is the case for the till core used in this study 207 (Table 3).

Table 4 presents the compaction state of the materials for each test. In accordance with practice 209 (e.g. SEBJ 1987), the water content for the till during compaction was fixed slightly above the optimum 210 water content of the standard Proctor compaction test (i.e. $\left.w_{\mathrm{opt}}+0.5\right)$. The till was compacted in two 211 12.5-cm thick layers. The core was compacted using a pneumatic hammer with a 5.1-cm square metal 212 plate. A relative compaction, $\mathrm{RC}$, of $97 \%$ with respect to the maximal dry density from the standard 213 Proctor compaction test was targeted. Filter materials that did not fulfill the filter criteria (Filters G1, G2 214 and G3) were dumped to limit the impact of filter compaction on erosion. A relative density index, $I_{\mathrm{d}}$, of $21570 \%$ was aimed for material 2 C. All materials were carefully placed to prevent segregation.

217 period of 24 hours (first overflow level on Figure 2a). The duration of the saturation phase is critical since 218 steady state conditions are more representative of actual field conditions. Numerical simulations using 219 COMSOL presented in Dumberry et al. (2015) helped to predict the unsaturated behaviour of the tested 220 specimens and to estimate the saturation period required for each increment. After the saturation period, 
221 the water level was gradually increased by increments of $5 \mathrm{~cm}$ and held constant for 12 hours after each 222 increment. The procedure was repeated until the maximum upstream water level was reached (eighth 223 overflow level on Figure 2a). Depending on the filter material permeability, the maximum upstream water 224 level was limited either by the maximum inlet flow rate (maximum flow rate of the faucet) or the 225 elevation of the eighth overflow valve (Figure 2a). Test $3 a$ was conducted at the end of Test 3 using the 226 same specimen. For this test, the upstream water level was varied between its two extreme positions (i.e. 227 levels 1 and 8) cyclically in time. For each cycle, the water level was held constant for 1 hour. Six cycles 228 were completed for this test.

The model and the test procedures were designed to measure or calculate the parameters that 230 affect the erosion mechanisms at the crest of an embankment dam. Pore pressures and suctions were 231 recorded manually every 30 minutes with the open piezometers and automatically every 15 seconds with 232 the pressure transducers. Flow rate and turbidity measurements were also obtained manually every 23330 minutes. Eroded sediments were collected at the outlet of the test setup to be weighted after drying and 234 analyzed using sieve analysis for the sand fraction and laser diffraction for the fine fraction. At the end of 235 each test, images recorded from the downstream camera were analyzed using DIC, while the images 236 obtained from the general view mainly served to describe qualitatively the progression of erosion. For 237 Tests 3 and 4, $\mu \mathrm{CT}$ analyses were completed on specimens collected using thin-walled aluminum 238 samplers with a diameter of $10 \mathrm{~cm}$ and a length of $20 \mathrm{~cm}$. The specimens were collected at the 239 downstream and upstream edges of the top of the core, at the centre of the basin along the axis 240 perpendicular to water flow (Figure 5e). Dumberry (2017) provides details on the specifications and 241 parameters of the laser diffraction device, digital cameras, pressure transducers and the flowmeter. It also 242 presents the turbidity and pore pressure results obtained during the tests. These results are not presented 243 herein. 


\section{Digital Image Correlation and X-ray microcomputed tomography}

245 Digital image correlation (DIC), allows displacement and strain fields in a soil section to be computed 246 (e.g. White et al. 2003). The principles of DIC can be summarized as follows. Several images are 247 captured with a digital camera. Sub-images of image A (test patches) are compared with larger sub248 images of image B (search patches). The most probable test patch displacement from image A within the 249 search patches of image B is then estimated with a cross-correlation technique. This procedure is then 250 repeated by comparing subsequent images, until all images have been examined. Displacement fields are computed from the conversion between pixel and length coordinates.

For this project, images were analyzed using PIVlab (Thielicke and Stamhuis 2014a), an opensource MATLAB code for DIC. The displacements were calculated using a direct Fourier transform correlation with multiple passes (FFT window deformation). Pre-processing parameters included a filter enhancing the contrast in the images and two passes with interrogation areas varying from 512 to 256 pixels. A calibration grid was placed on the wall prior to each test for pixel/length conversion. Aberrant vectors obtained during the analyses were removed with a standard deviation filter.

Microcomputed tomography is a non-destructive technique that uses the attenuation of X-rays to 259 build a 3D reconstruction of a specimen. During a scan, a source sends X-rays that travel in straight lines 260 through the specimen. Some of the X-rays are absorbed by the specimen, reducing their intensity. During 261 the scan, the specimen is rotated about a vertical axis. For each position, X-ray attenuation forms a 262 shadow image on a flat panel detector that converts the X-ray energy into light. After a full rotation of the 263 specimen, its volume is divided into a large number of 3D cells (voxels). Using the shadow images, a 264 linear X-ray attenuation value is estimated for each cell to create the 3D reconstitution of the object. 265 Typically, voxels that display a strong X-ray attenuation (i.e. solid grains) are represented as brighter region, while darker regions represent materials with low attenuation (i.e. water and air in the voids). 
For the purpose of this study, a XT H $225 \mu \mathrm{CT}$ scan from Nikon was used. For the scans presented in this paper, beam energy and current were respectively set to $221 \mathrm{kV}$ and $184 \mu \mathrm{A}$. The exposure time was set to $500 \mathrm{~ms}$ for each shadow image. The specimen location inside the $\mu \mathrm{CT}$ scan allowed a minimum voxel size of $80 \mu \mathrm{m}$. As a result, it was not possible to distinguish individual fine particles in the till. A beam hardening correction was applied to the images to reduce streak artefacts from dense structures in the specimen. Beam hardening was also reduced using a copper filter placed between the X-ray source and the specimen. Preliminary segmentation and volume rendering were realized with Visual Graphics Studio MAX 2.2. Details on the parameters used for DIC and $\mu$ CT analyses are presented in Dumberry (2017).

\section{$277 \quad$ Results}

\section{General observations}

Cameras allowed qualitative observation of erosion to be made for each test. Figure 4 shows photographs representing the state of the core/filter interface at 1) the initial stage of the test (before saturation), 2) when the water level is at the top of the core, and 3) at the end of the test. Results from Tests 1 and 2 showed significant erosion. For these core/filter combinations, erosion was first initiated

283 locally along the downstream slope of the core, and then gradually progressed toward the horizontal 284 interface as the upstream water level and hydraulic gradient increased, thus inducing a piping 285 phenomenon (Fell and Fry 2007). As erosion progressed, the core material located above the pipe was 286 continuously being eroded. Vertical settlements and reorganization of grains inside the filter material 287 were also observed during the progression of the erosion. Tests 1 and 2 had to be stopped after reaching, 288 respectively, the third and fourth upstream water levels because the flow rate at the inlet did not match the 289 high permeability of the filter materials. Maximum flow rates of 45 and $41 \mathrm{~L} / \mathrm{min}$ were measured for 290 Tests 1 and 2, respectively, which correspond to water levels 3 and 4 . At the end of these tests, particle re- 
291 gradation was observed along the downstream slope (i.e. paving effect). As water velocities increased,

292 fine particles were eroded preferentially at the downstream edge of the core. This allowed the remaining 293 larger grains to act as a natural intermediate filter layer between the original filter and core materials. 294 Figure 5a represents a detailed view of the core/filter downstream interface where a paving effect was 295 observed.

Even though the filter material of Test 3 did not satisfy the filter criterion of Table 2, no significant erosion occurred. Some local instability appeared on the downstream slope (Figure 4), but no piping was observed within the core material. For Test 4, the filter material satisfied the filter criteria and no erosion occurred on the downstream slope or along the horizontal interface. Maximum flow rates of 38 and $0.70 \mathrm{~L} / \mathrm{min}$ were obtained for Tests 3 and 4, respectively, corresponding to water levels 8 and 7 .

For all tests, local instabilities were observed during the saturation phase along the upstream slope of the core material. Erosion along the horizontal interface occurred mainly for Tests 1, 2 and 3, but was smaller in scale compared to the erosion observed along the downstream slope. For all water levels during which eroded particles were collected at the outlet, the propagation of erosion varied with time. For a 12hour water level stage, erosion lasted less than 1 hour. Erosion apparently ceased after this initial erosion period, irrespective of the filter used here.

\section{Particle Size Distribution and Mass Balance}

Particle size distribution and mass balance analyses provided information on the propagation of

310 erosion with time and the type of material being eroded. Table 5 presents mass balance results for each

311 test. The percentage of eroded dry mass was computed considering the initial dry mass of the core 312 material after placement $(190.5 \mathrm{~kg})$. Table 5 shows that major erosion was triggered when the upstream 313 water level reached the core/filter interface (level 2) for Test 2. The same phenomenon was observed for

314 Test 1, based on visual observation. For Test 3, erosion was initiated during level 3, when the water table 
315 overtopped the core by $5 \mathrm{~cm}$. However, no significant erosion occurred when the upstream water level 316 was at the same elevation as the core/filter horizontal interface. For Tests 1 to 3, the greatest amount of 317 eroded mass was collected during level 3. For Test 3a, the erosion rate gradually decreased as the number 318 of cycles increased. These results suggest that, in some conditions, even a filter that does not meet filter 319 criteria can control core particle erosion.

Figure 6 shows the particle-size distribution of the sediments eroded and collected at the outlet for each water level. The particle-size analyses demonstrate that the eroded particles tended to become coarser as the water level increased, especially for Tests 1 and 2. Eroded particles collected from levels 4 to 8 for Test 3 were similar in terms of particle-size distributions. Particle-size gradation curves of sediments collected during Test 3 a were finer than those obtained for levels 4 to 8 for Test 3 . photographs were respectively used for the calculations. Displacement vectors are displayed at their real scale, which means that a vector length of 1 pixel represents a displacement of 1 pixel during the test. The DIC results show the complex distribution of displacement vectors (i.e. rapid orientation changes) where

332 the pipe was formed. These rapid orientation changes are due both to large local deformations and patch 333 comparison issues. The displacement vectors also show mean vertical settlements of approximately 7 and $3345 \mathrm{~mm}$, for Tests 1 and 2, respectively, within the filter material at the downstream edge of the core 335 material. The width of this settlement zone corresponds to the length of the erosion pipe. The settlement 336 occurred simultaneously as the pipe progressed upward and as the core particles were eroded. In some 337 parts of the section, for example over the edge of the core, the vertical displacements seem to increase 338 downward, possibly indicating arching and an increase in porosity above the erosion zone. No major 
particle displacements were observed within the core material, away from the interface and the pipe formation.

For Test 3, a total of 55 photographs were used for the calculations. Displacement vectors are represented at a magnified scale of 10:1 with a length of 10 pixels representing a displacement of 1 pixel. This magnification was used because particles displacements and the associated deformations were very small for this test relative to Tests 1 and 2. It can be noted that the displacements are concentrated at the downstream edge of the core. The mean vertical settlement is approximately $0.6 \mathrm{~mm}$. No major migration of filter grains or contact erosion was observed. Results show that the vertical component of the displacement vector is predominant.

For Test 4, a total of 11 photographs were used for the calculations. Displacement vectors are represented with a scale of 75:1 as displacements were very small. The images show vertical settlements in the filter, and along the interface between till and filter, both at the top of the core and on the downstream slope. The mean vertical settlement within the filter is approximately $0.2 \mathrm{~mm}$.

352 Unlike Tests 1 and 2, local instabilities and vertical settlements due to erosion for Tests 3 and 4 are 353 difficult to distinguish by simply comparing visually the initial and final photographs. The field of 354 displacement vectors obtained in Test 4, where no erosion occurred, appears typical of the expected 355 behaviour of a till core showing settlements during the wetting stage, therefore giving confidence to 356 the DIC methods used herein.

The DIC results clearly show that the magnitude of the displacement vectors is related to the

358 volume of till eroded during each test. Figure 8 shows the relationship between the mean displacement 359 magnitude (in $\mathrm{mm}$ ) obtained with DIC and the total eroded mass as a percentage of initial core mass as 360 presented in Table 5. Results are presented for the complete tests and individual water level stages. 361 The mass of fine sediments collected for each test in the water tank at the outlet of the sedimentation 362 column was uniformly distributed among each water level. This assumption is a simplification as the 
363 particle size distribution of the eroded sediments and the fraction of sediments that bypassed the 364 sedimentation column varied with time. The mean displacement vector is subvertical for all tests, 365 except for Test 4 that showed relatively small displacements. This is consistent with the displacement 366 vectors presented in Figure 7. It should be noted that some of the eroded mass for Test 3 could come 367 from the filter as $29 \%$ of the G3 grain size distribution was finer than the slot width (5 mm). 368 However, since there was no erosion for material 2C, it appears unlikely that material G3 was eroded 369 through the slot.

\section{X-ray Microcomputed Tomography}

Figure 9 presents the $\mu \mathrm{CT}$ scan results for Tests 3 and 4 from different viewpoints. For Test 3, the scan shows local instabilities along the upstream slope during the saturation phase. The post-experiment

374 downstream interface of the core is uneven and rougher than the initially undisturbed interface. This could 375 be caused either by the hydraulic forces that eroded the core particles during the experiments, the effect of 376 the compaction effort on the core surfaces regularity or the remoulding effects during sampling. For 377 Test 4, a similar pattern was observed regarding local instabilities along the interfaces of the core/filter 378 materials, with the exception that the irregularity seems to be less prominent. This is expected since no 379 eroded particles were collected at the outlet of the test setup. Accordingly, the downstream plan view of the tested sample shows a relatively intact post-experiment core interface.

382 Discussion

Based on the results presented in Table 5, some particles from the core were collected at the test setup outlet for Tests 1 to 3 . This implies that the three filters that did not meet the filter criteria did not contain pore constrictions that were small enough to retain the fine particles of the core material.

387 till was eroded during the test, including the cyclic core overtopping stages at the end of the test. It is not 
clear if this mass loss is significant. For comparison purposes, it has been observed that the global performance of the WAC Bennett Dam, located in British Columbia, Canada, was affected by a much smaller percentage of mass loss (Garner and Fannin 2010). Indeed, the presence of two sinkholes of at least $1,400 \mathrm{~m}^{3}$ within a total volume of about $2.5 \times 10^{7} \mathrm{~m}^{3}$ of till material caused significant changes in

392 flow rates and pressure measurements within the dam. Based on this comparison, it can be inferred that 393 erosion rates as low as $0.25 \%$ could potentially have a negative influence on the performances of 394 embankment dams. It thus appears important to put more effort on the modelling, both numerical and physical, of the evolution of minor erosion events for embankment dams. Better modelling tools would allow erosion thresholds to be defined.

Visual analysis of erosion was useful to understand the erosion mechanisms at the top of the core.

398 For Tests 1 and 2, piping was initiated along the downstream slope, before complete core overtopping 399 (Figure 4). Erosion along the downstream slope of the core during overtopping experiments has been observed by other researchers (e.g. Gregoretti et al. 2010; Javadi and Mahdi 2014). However, in these cases, piping developed while the core material was completely saturated and overtopped. A review of the photographs for Tests 1 and 2 shows the pipe to be parallel to the streamline delimiting the saturated/unsaturated conditions within the core. For Tests 1 and 2, it appears that contact erosion at the horizontal interface between till and filter was less significant than the erosion due to piping. Based on these results, it can be inferred that erosion of the downstream slope would be more critical than erosion along the core/filter horizontal interface for actual dams. Also, hydraulic gradients before core overtopping would be much higher for a real dam. As a result, piping along the downstream slope of the core would probably be initiated before the water level reached the top of the core. This implies that combinations of filter and core materials that are stable when the water level is below the core summit would not be negatively impacted by core overtopping.

A qualitative examination of the post-experiment results from Tests 1 and 2 reveals the 
413 identified. As fine particles from the till were eroded through the filter, the core material along the 414 downstream interface became coarser. This created a relatively uniform intermediate filter layer that was 415 coarser than the original core material, but finer than the filter. This phenomenon, known as paving or 416 bridging, has been observed previously for broadly graded core materials (e.g. Lafleur et al. 1989; 417 Wörman 1996; Dionne and Konrad 2015). Other researchers have referred to the self-healing capability 418 of broadly graded materials (e.g. Milligan 2003; Fell and Fry 2007). A post-test visual analysis of the 419 surfaces of the core material for Test 2 showed a much coarser matrix at the downstream edge of the core 420 (Figure 5d) compared to the upstream edge (Figure 5c). As shown on Figure 5d, erosion was relatively 421 homogeneous along the width of the test setup.

According to Table 5, the percentage of eroded particles decreased with time after a critical water correlate with the upstream water level once the erosion was initiated. Wörman and Olafsdottir (1992) explained this trend in terms of hydraulic gradient. The paving effect described previously probably also explains why the erosion rate decreased during the later stages of each test. the flow rate at the outlet and the saturated thickness of the filter material (Figure 4, end of final stage).

429 Seepage velocity values of 3.9 and $2.1 \mathrm{~cm} / \mathrm{s}$ are calculated respectively for Tests 1 and 2 . Real pore water 430 velocity values of 10.5 and $5.8 \mathrm{~cm} / \mathrm{s}$ can be obtained for the same tests by dividing the seepage velocity 431 values by the G1 and G2 filter porosity values $(e /(e+1)$ in Table 4$)$. These water velocity values are 432 relatively close to the critical velocity of $10 \mathrm{~cm} / \mathrm{s}$ for interfacial erosion and bridge scour for non-plastic 433 fines and fine sand (Briaud 2008), and very high with respect to the critical velocity for piping (Richards 434 and Reddy 2012). This could explain the prevalence of piping failure and the paving effect which would 435 correspond to the erosion of fine sand and non-plastic fines (Figure 6). 
For Test 4 , the correctly designed filter material was efficient at retaining the core particles. No

437 particles were collected at the test setup outlet. Important differences between the test setup and actual

438 field conditions must however be noted. First, the filter material used for this test was densely compacted.

439 However, for actual field conditions, under-compacted zones are likely to be found in areas where

440 material placement poses challenges, for instance in the vicinity of instruments or spillways. In that sense,

441 some studies have demonstrated that filter criteria should be revised for under-compacted core material

442 (Watabe et al. 2000; Soroush et al. 2016).

The degree of segregation and heterogeneity is also a significant difference between the

444 laboratory model presented in this paper and actual field conditions. Milligan (2003) mentioned that

445 internal erosion of broadly graded till is more likely to be the consequence of segregation during 446 placement rather than from hydraulic conditions or geometric instability. For this laboratory study, 447 placement of filter G3 created thin layers of coarser material and discontinuous voids within the filter 448 (Figure 5b). These coarse-grained layers influenced the path followed by the eroded core particles, as they 449 tended to migrate horizontally within these layers. Segregation of filter $2 \mathrm{C}$ for Test 4 also created 450 localized void networks along the upstream interface. Local instabilities were observed in these large 451 voids (Figure 4). Wörman and Olafsdottir (1992) and Smith (2012) also acknowledged that even limited 452 spatial variations in soil characteristics can increase the risk of erosion.

454 technique was able to calculate the displacements in the material surrounding the erosion zones. However, 455 the high local deformation rates associated with particles migration or seepage were not always handled 456 properly by this technique. For instance, Figure 7 showed the presence of randomly oriented vectors 457 along the pipe. Changes in water content and the fine texture of the till with respect to the resolution of 458 the photographs are other issues with DIC for this model. DIC remains a promising tool for studying 459 erosion processes despite these limitations. PIV algorithms that handle discrete displacement have 
recently been developed (e.g. Andò et al. 2012). These algorithms could help modify PIVlab to consider erosion.

Reconstruction of $\mu \mathrm{CT}$ models provided additional information on erosion away from the sidewalls of the test setup. Along with DIC analyses and photographs of the post-test core material (Figures $5 \mathrm{c}$ and $6 \mathrm{~d}$ ), $\mu \mathrm{CT}$ demonstrates that the influence of sidewall on erosion was negligible. Reconstruction of $\mu \mathrm{CT}$ models remains a relatively new tool in geotechnical engineering. With proper segmentation techniques (e.g. Taina et al. 2007; Kim et al. 2013), the local grain size distribution of the intermediate filter associated with paving could be calculated. $\mu \mathrm{CT}$ analyses can also give detailed morphological information about the shape, size distribution and connectivity of the pore network within the specimen. This could provide interesting information knowing that some researchers recently studied the effect of constriction size in soils on their geotechnical behaviour (Indraratna et al. 2011; Shire et al. 2014; To et al. 2015).

\section{Conclusion}

In Quebec, most large dams are zoned earthfill structures with a glacial till core protected by filters. This paper looked at the erosion mechanisms at the local scale during core overtopping by using a physical model representative of most field conditions, and image processing techniques such as DIC and $\mu \mathrm{CT}$. In total, four tests involving impoundment of the upstream reservoir eventually above the core top were performed with the same core material, a glacial till from northern Quebec, and different filter materials. The first three tests were conducted with uniform gravel filters with $D_{15}$ of $22 \mathrm{~mm}(\mathrm{G} 1), 8 \mathrm{~mm}$ (G2) and $2.5 \mathrm{~mm}$ (G3). These filters did not fulfill the filter criteria considered. The fourth filter, a wellgraded sand with a $D_{15}$ of $0.5 \mathrm{~mm}(2 \mathrm{C})$, satisfied the filter criteria and was more representative of actual field conditions. Hydraulic boundaries were defined by a variable upstream water level initially fixed $5 \mathrm{~cm}$ under the top of the core for a saturation phase of 24 hours. Water levels were then increased by 
increments of $5 \mathrm{~cm}$ each 12 hours. Combination of the till core and filter G3 was also tested by varying cyclically the water level from the highest to the lowest levels.

No eroded particles were collected downstream for the test involving filter $2 \mathrm{C}$. Uniform gravel filters did not adequately protect the core material, since eroded particles were collected downstream. The most pronounced erosion was associated with the coarsest filter material. For the tests involving Filters G1 and G2, a pipe appeared along the downstream slope when the water level reached the top of the core. The pipe was parallel to the flow line. Erosion during these tests was mainly due to the progression of the pipe within the core material rather than contact erosion along the horizontal interface. For the first three tests, erosion mainly occurred when the water level reached the core/filter interface and the subsequent level. The erosion rate decayed in time as the hydraulic gradient increased. The self-healing process that was observed at the interface between core and filter explains this decrease in erosion rate. For each water level increment, erosion mainly took place during the first hour of the imposed hydraulic condition.

The DIC technique clearly showed that the displacement vector magnitude is directly proportional to the volume of till eroded. DIC results provided detailed information on the vertical settlements and grains reorganization within the filter material, as the core was being eroded. $\mu \mathrm{CT}$ results put the emphasis on the post-experiment downstream interface of the core, which became uneven and rougher than the initially undisturbed interface as the hydraulic gradient increased. For filters $\mathrm{G} 3$ and $2 \mathrm{C}$, results showed that erosion mainly appeared along the downstream slope. $\mu \mathrm{CT}$ also showed that there was no wall effect with the setup and conditions used herein.

Experimental results for this study will further be analyzed using a numerical model based on a multiscale approach, combining particle scale modelling with the discrete element method (open-source code YADE), and COMSOL. Upcoming experimental runs will also be conducted using the same setup to study the effect of unsaturated conditions in embankment dams on internal erosion. The reduced-scale nature of this study nevertheless necessitates caution with regards to the inferences drawn for large 
embankment dams. The effect of the spatial configuration of the soil components must also be considered. Further experimental studies should focus on the downstream slope stability of the core material in core overtopping conditions. Filter efficiency in such conditions is also an issue, as to whether pore pressures, flow rates and effective stress have an impact on the filter performance.

\section{Acknowledgments}

The authors are grateful to the Natural Sciences and Engineering Research Council of Canada

515 (NSERC) and Hydro-Québec for their financial support through a Collaborative Research and 516 Development grant (CRD). The authors would like to acknowledge the technical support of Sébastien 517 Ménard for the design and construction of the test setup and the help of two graduate students who 518 monitored the test setup at night. The authors would also like to thank two anonymous reviewers whose 519 comments and suggestions helped to improve the manuscript.

\section{$521 \quad$ References}

522 Andò, E., Hall, S.A. and Viggiani, G. 2012. Grain-scale experimental investigation of localised deformation in sand: a discrete particle tracking approach. Acta Geotechnica, 7: 1-13.

ASTM. 2007. Standard test method for particle-size analysis of soils (D 422). ASTM International, West Conshohocken, PA, USA.

ASTM. 2012. Standard test methods for laboratory compaction characteristics of soil using standard effort (12 $\left.400 \mathrm{ft}^{-\mathrm{lbf}^{3}}\left(600 \mathrm{kN}-\mathrm{m} / \mathrm{m}^{3}\right)\right)$ (D 698). ASTM International, West Conshohocken, PA, USA.

ASTM. 2014a. Standard test methods for maximum index density and unit weight of soils using a vibratory table (D 4253). ASTM International, West Conshohocken, PA, USA. 
ASTM. 2014b. Standard test methods for minimum index density and unit weight of soils and calculation of relative density (D 4254). ASTM International, West Conshohocken, PA, USA.

Beguin, R., Philippe, P. and Faure, Y.H. 2013. Pore-scale flow measurements at the interface between a sandy layer and a model porous medium: application to statistical modeling of contact erosion. Journal of Hydraulic Engineering, 139(1): 1-11.

Binner, R., Homberg, U., Prohaska, S., Kalbe, U. and Witt, K.J. (2010). Identification of descriptive parameters of the soil pore structure using experiments and $\mu \mathrm{CT}$ data. In Proceedings of the 5th International Conference on Scour and Erosion, San Francisco, CA, USA, 7-10 November 2010. ASCE, Reston, VA, USA, pp. 397-407.

Boccalini, F., Chen, Z., Omidva, M. and Iskander, M. 2015. A study of plane strain pile jacking and driving in granular media. In Proceedings of the International Foundations Congress and Equipment Expo (IFCEE), San Antonio, TX, USA, 17-21 March 2015. ASCE, Reston, VA, USA, pp. $738-747$.

Boulton, G.W. 1977. The development of geotechnical properties in glacial tills. In Glacial till: An interdisciplinary study. Edited by R. F. Legget. The Royal Society of Canada in co-operation with the National Research Council of Canada, Ottawa, ON, Canada. pp. 292-303.

Briaud, J.L. 2008. Case Histories in Soil and Rock Erosion: Woodrow Wilson Bridge, Brazos River Meander, Normandy Cliffs, and New Orleans Levees. Journal of Geotechnical and Geoenvironmental Engineering, 134(10): 1425-1447.

Chapuis, R.P. 2004. Predicting the saturated hydraulic conductivity of sands and gravel using effective diameter and void ratio. Canadian Geotechnical Journal, 41(5): 787-795.

Chapuis, R.P. 2012. Predicting the saturated hydraulic conductivity of soils: A review. Bulletin of Engineering Geology and the Environment, 71(3): 401-434.

Dionne, P.O. and Konrad, J.M. 2015. An experimental study of contact erosion between a till core and coarser crest and filter material. In Proceedings of the 68th Canadian Geotechnical Conference 
and 7th Canadian Permafrost Conference, Quebec city, QC, Canada, 20-23 September 2015. Canadian Geotechnical Society, Richmond, BC, Canada.

Dumberry, K. 2017. Étude expérimentale des mécanismes d'érosion durant le franchissement de noyau. Master Thesis, Department of Construction Engineering, École de technologie supérieure, Montréal, QC, CAN.

Dumberry, K., Duhaime, F. and Éthier, Y.A. 2015. Experimental study of contact erosion during core overtopping. In Proceedings of the Canadian Dam Association Annual Conference, Mississauga, ON, Canada, 3-8 October 2015. Canadian Dam Association, Toronto, ON, Canada, pp. 214-218.

Fell, R. and Fry, J.J. 2007. The state of the art of assessing the likelihood of internal erosion of embankment dams, water retaining structures and their foundations. In Internal erosion of dams and their foundations. Edited by R. Fell and J.J. Fry. Taylor \& Francis, London, UK. pp. 1-23.

Fell, R., MacGregor, P., Stapledon, D., Bell, G. and Foster, M. 2015. Geotechnical engineering of dams. Taylor \& Francis, London, UK.

FEMA. 2014. Technical manual: Overtopping protection for dams. Best practices for design, construction, problem identification and evaluation, inspection, maintenance, renovation and repair. FEMA P-1015, USBR, Denver, CO, USA.

Foster, M., Fell, R. and Spannagle, M. 2000. Statistics of embankment dam failures and accidents. Canadian Geotechnical Journal, 37(5): 1000-1024.

Garner, S.J. and Fannin, R.F. 2010. Understanding internal erosion: A decade of research following a sinkhole event. International Journal on Hydropower and Dams, 17(3): 93-98.

Gregoretti, C., Maltauro, A. and Lanzoni, S. 2010. Laboratory experiments on the failure of coarse homogeneous sediment natural dams on a sloping bed. Journal of Hydraulic Engineering, 136(11): 868-879.

Guidoux, C., Faure, Y.H., Beguin, F. and Ho, C.C. 2010. Contact erosion at the interface between granular coarse soil and various base soils under tangential flow condition. Journal of Geotechnical and Geoenvironmental Engineering, 136(5): 741-750. 
Indraratna, B., Nguyen, V. and Rujikiatkamjorn, C. 2011. Assessing the potential of internal erosion and suffusion of granular soils. Journal of Geotechnical and Geoenvironmental Engineering, 137(5): 550-554.

Javadi, N. and Mahdi, T.F. 2014. Experimental investigation into rockfill dam failure initiation by overtopping. Natural Hazards, 74: 623-637.

Kim, F.H., Penumadu, D., Gregor, J., Kardjilov, N. and Manke, I. 2013. High-resolution neutron and Xray imaging of granular materials. Journal of Geotechnical and Geoenvironmental Engineering, 139(5): 715-723.

Lafleur, J., Mlynarek, J. and Rollin, A.L. 1989. Filtration of broadly graded cohesionless soils. Journal of Geotechnical Engineering, 115(12): 1747-1768.

Lafleur, J., Montès, P. and Alicescu, V. 1999. Internal stability of particles in dam cores made of broadly graded moraines. In Proceedings of the 52nd Canadian Geotechnical Conference, Regina, SK, Canada, 25-27 October 1999. Canadian Geotechnical Society, Richmond, BC, Canada, pp. 551558.

Maknoon, M. and Mahdi, T.F. 2010. Experimental investigation into embankment external suffusion. Natural Hazards, 54(3): 749-763.

Milligan, V. 2003. Some uncertainties in embankment dam engineering. Journal of Geotechnical and Geoenvironmental Engineering, 129(9): 785-797.

Pan, B., Qian, K., Xie, H. and Asundi, A. 2009. Two-dimensional digital image correlation for in-plane displacement and strain measurement: A review. Measurement, Science and Technology, 20: 117.

Pirnia, P., Duhaime, F., Éthier, Y.A., Dubé, J.S. 2016. Development of a multiscale numerical modelling tool for granular materials. In Proceedings of the 69th Canadian Geotechnical Conference, Vancouver, BC, Canada, 2-5 October 2016. Canadian Geotechnical Society, Richmond, BC, Canada. 
607

608

609

610

611

612

613

614

615

616

617

618

619

620

621

622

623

624

625

626

627

628

629

630

631

Richards, K.S., and Reddy, K.R. 2012. Experimental investigation of initiation of backward piping in soils. Géotechnique, 62(10): 933-942.

SEBJ. 1987. Le complexe hydroélectrique de La Grande Rivière : Réalisation de la première phase. Chenelière, Montreal, QC, Canada.

Saint-Arnaud, G. 1995. The high pore pressure within embankment dams: an unsaturated soil approach. Canadian Geotechnical Journal, 32: 892-898.

Seo, M.W., Ha, I.S., Im, E.S., Kim, H.S., Kim, Y.S., and Kim, T.H. 2006. Centrifuge tests for evaluating effects of water level change on fill dam behavior. In Proceedings of the 6th International Conference on Physical modelling in Geotechnics, Honk Kong, 4-6 August 2006. Taylor \& Francis, London, UK, pp. 431-434.

Sherard, J.L., Dunnigan, L.P. and Talbot, J.R. 1984. Basic properties of sand and gravel filters. Journal of Geotechnical Engineering, 110(6): 684-700.

Shire, T., O'Sullivan, C., Hanley, K.J. and Fannin, R.J. 2014. Fabric and effective stress distribution in internally unstable soils. Journal of Geotechnical and Geoenvironmental Engineering, 140(72): 111.

Smith, M. 2012. Assessment of the internal stability of a dam core. La Houille Blanche, (4-5): 54-59.

Soroush, A., Tabatabaie Shourijeh, P. and Shams Molavi, S. 2016. Applicability of filter design criteria for wet core embankment dams in wet climates. Geotechnical Testing Journal, 39(3), 343-361.

Taina, I.A., Heck, R.J. and Elliot, T.R. 2007. Application of X-ray microcomputed tomography to soil science: A literature review. Canadian Journal of Soil Science, 88(1): 1-19.

Takano, D., Lenoir, N., Otani, J. and Hall, S.A. 2015. Localised deformation in a wide-grained sand under triaxial compression revealed by X-ray tomography and digital image correlation. Soils and Foundations, 55(4): 906-915.

Thielicke, W. and Stamhuis, E.J. 2014a. PIVlab (version 1.41). http://dx.doi.org/10.6084/m9.figshare.1092508. 
632 Thielicke, W. and Stamhuis, E.J. 2014b. PIVlab - Towards user-friendly, affordable and accurate Digital Particle Image Velocimetry in MATLAB. Journal of Open Research Software, 2:e30.

634 To, H.D., Galindo-Torres, S.A. and Scheuermann, A. 2015. Primary fabric fraction analysis of granular soils. Acta Geotechnica, 10: 375-387.

Tollner, E.W. and Verma, B.P. 1989. X-Ray $\mu \mathrm{CT}$ for quantifying water content at points within a soil body. Soil and Water Division of ASAE, 32(3): 901-905.

Van Beek, V.M., Van Essen, H.M., Vandenboer, K., Bezuijen, A. 2015. Developments in modelling of backward erosion piping. Géotechnique, 65(9): 740-754.

Watabe, Y., Leroueil, S. and Le Bihan, J.P. 2000. Influence of compaction conditions on pore-size distribution and saturated hydraulic conductivity of a glacial till. Canadian Geotechnical Journal, 37: 1184-1194.

White, D.J., Take, W.A. and Bolton, M.D. 2003. Soil deformation measurement using particle image velocimetry (PIV) and photogrammetry. Géotechnique, 55(7): 619-631.

Wörman, A. 1996. Constitutive equation for filtration of well graded base soil with flow parallel to 646 base/filter interface. In Proceedings of 2nd International Conference on Geofilters, Montreal, QC,

Wörman, A. and Olafsdottir, R. 1992. Erosion in a granular medium interface. Journal of Hydraulic Research, 30(5): 639-655.

Wörman, A. and Skoglund, M. 1992. Overtopping of the core in rockfill dams - Internal erosion. In Proceedings of the 2nd International Conference on Hydropower Development, Lillehammer, Norway, 16-18 June 1992. A.A. Balkema, Rotterdam, Netherlands, pp. 433-440.

Zhang, L.M. and Chen, Q. 2006. Seepage failure mechanism of the Gouhou rockfill dam during reservoir water infiltration. Soils and Foundations, 46(5): 557-568. 


\section{Figure Captions}

658 Figure 1: Schematic representation of core overtopping

659 Figure 2: (a) Layout of the physical model; (b) Photograph of the front of the model; (c) Photograph of 660 the back of the model

661 Figure 3: Particle-size distribution of the till core and filter materials

662 Figure 4: Photographs of Tests 1-4 before saturation, at the end of the stage during which the water level 663 was maintained at the core/filter interface and at the end of each test

664 Figure 5: (a) Intermediate filter layer created by paving at the downstream edge of the core for Test 1 665 (backside of the model); (b) Influence of segregation on migration patterns of eroded particles for Test 3 666 (frontside of the model); (c) Horizontal and sloped surfaces at the upstream edge (top view) of the core 667 for Test 2; (d) Horizontal and sloped surfaces at the downstream edge (top view) of the core for Test 2; 668 (e) $\mu \mathrm{CT}$ sampling locations

669 Figure 6: Particle-size distribution of the eroded mass collected: (a) Tests 1-2; (b) Tests 3-3a

670 Figure 7: Results from DIC analyses of two recorded images during an erosion stage for Tests 1-4 (vector 671 scales for each test are shown on the figure)

672 Figure 8: Relationship between mean displacement magnitude and total eroded mass as a percentage of 673 initial core mass

674 Figure 9: $\mu \mathrm{CT}$ results of downstream and upstream samples for Tests 3 and 4 from different viewpoints 675 


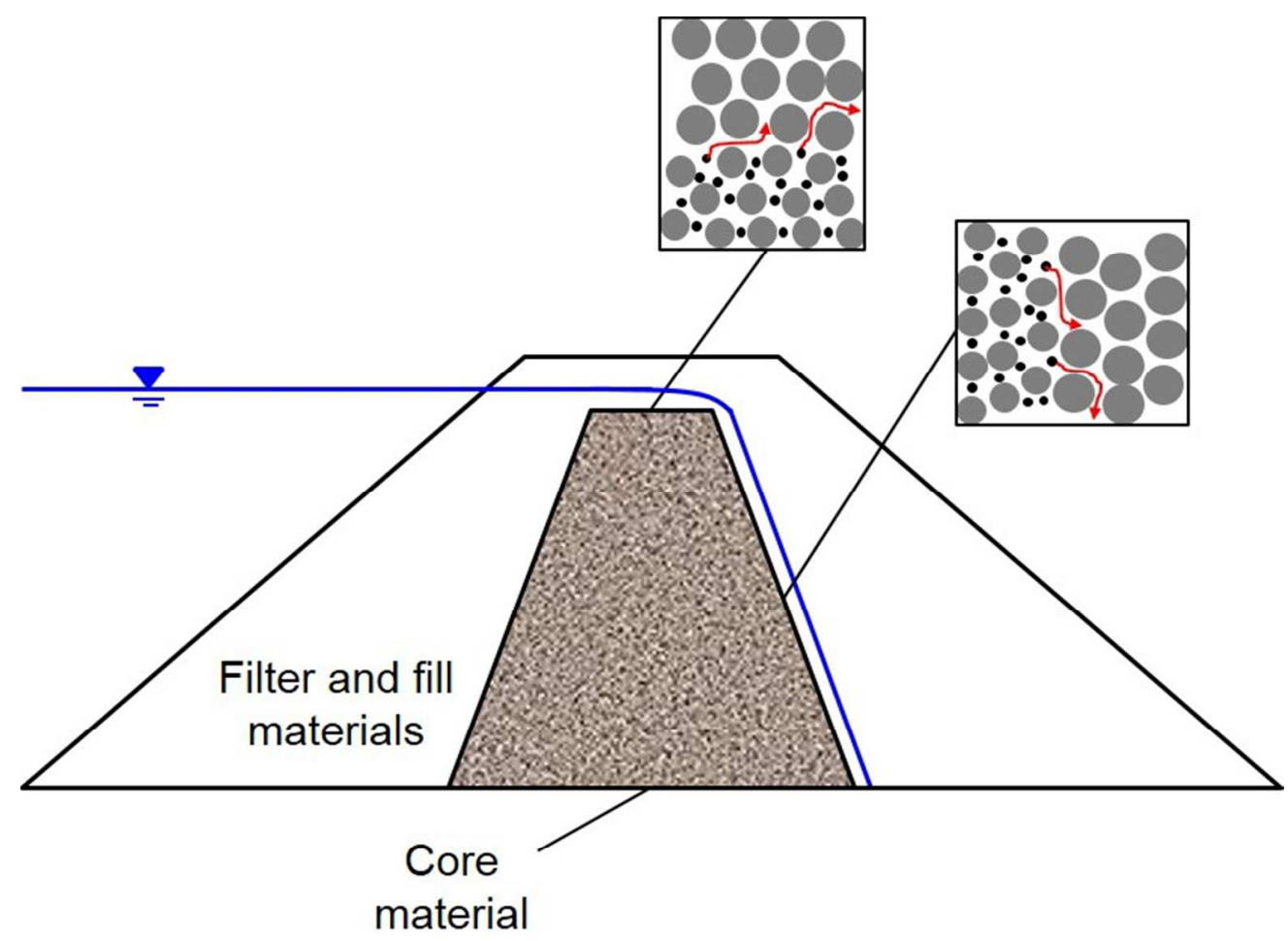

Figure 1: Schematic representation of core overtopping $142 \times 107 \mathrm{~mm}(150 \times 150 \mathrm{DPI})$ 


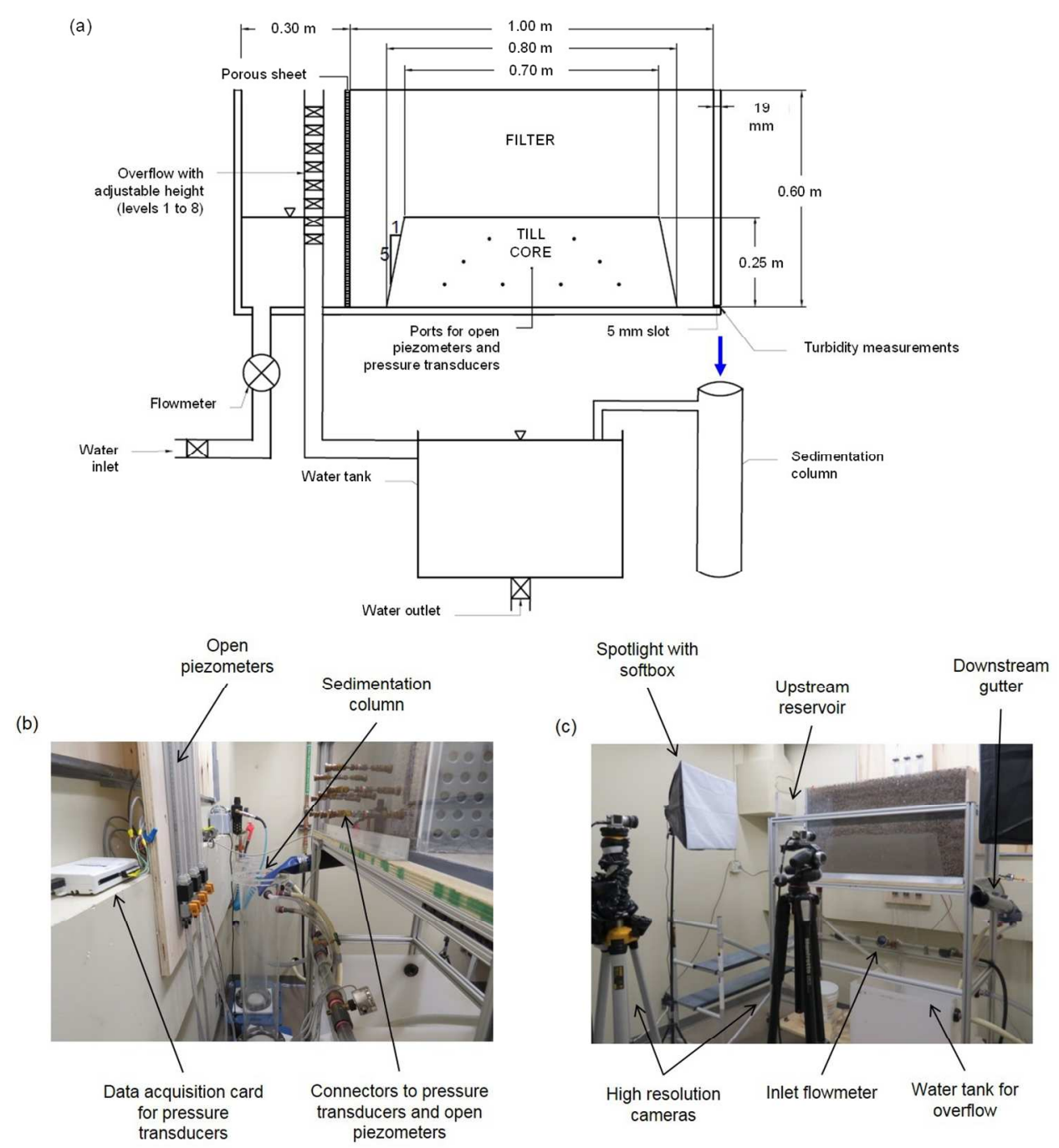

Figure 2: (a) Layout of the physical model; (b) Photograph of the front of the model; (c) Photograph of the back of the model

$246 \times 264 \mathrm{~mm}(150 \times 150$ DPI $)$ 


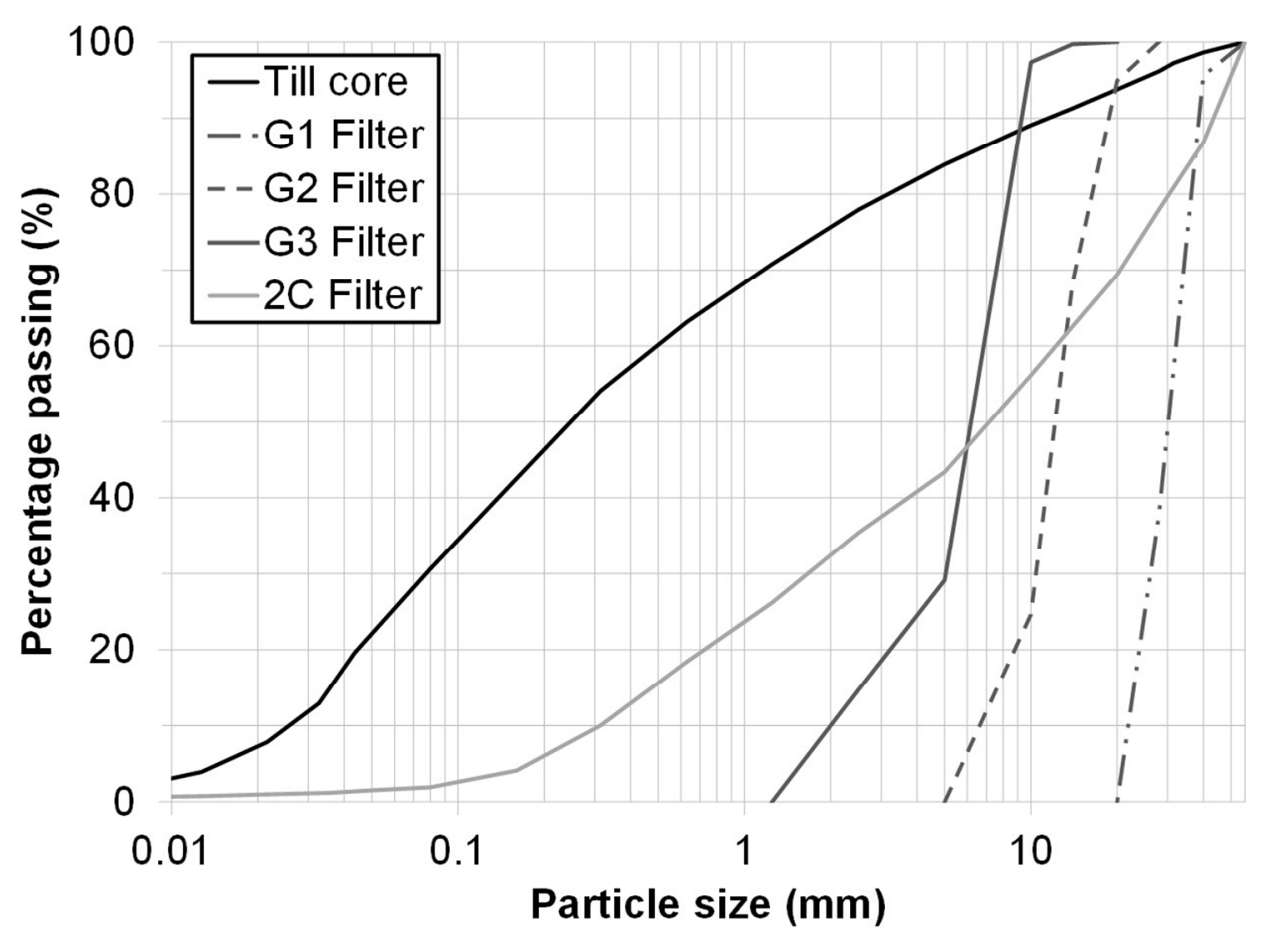

Figure 3: Particle-size distribution of the till core and filter materials $222 \times 161 \mathrm{~mm}(150 \times 150 \mathrm{DPI})$ 


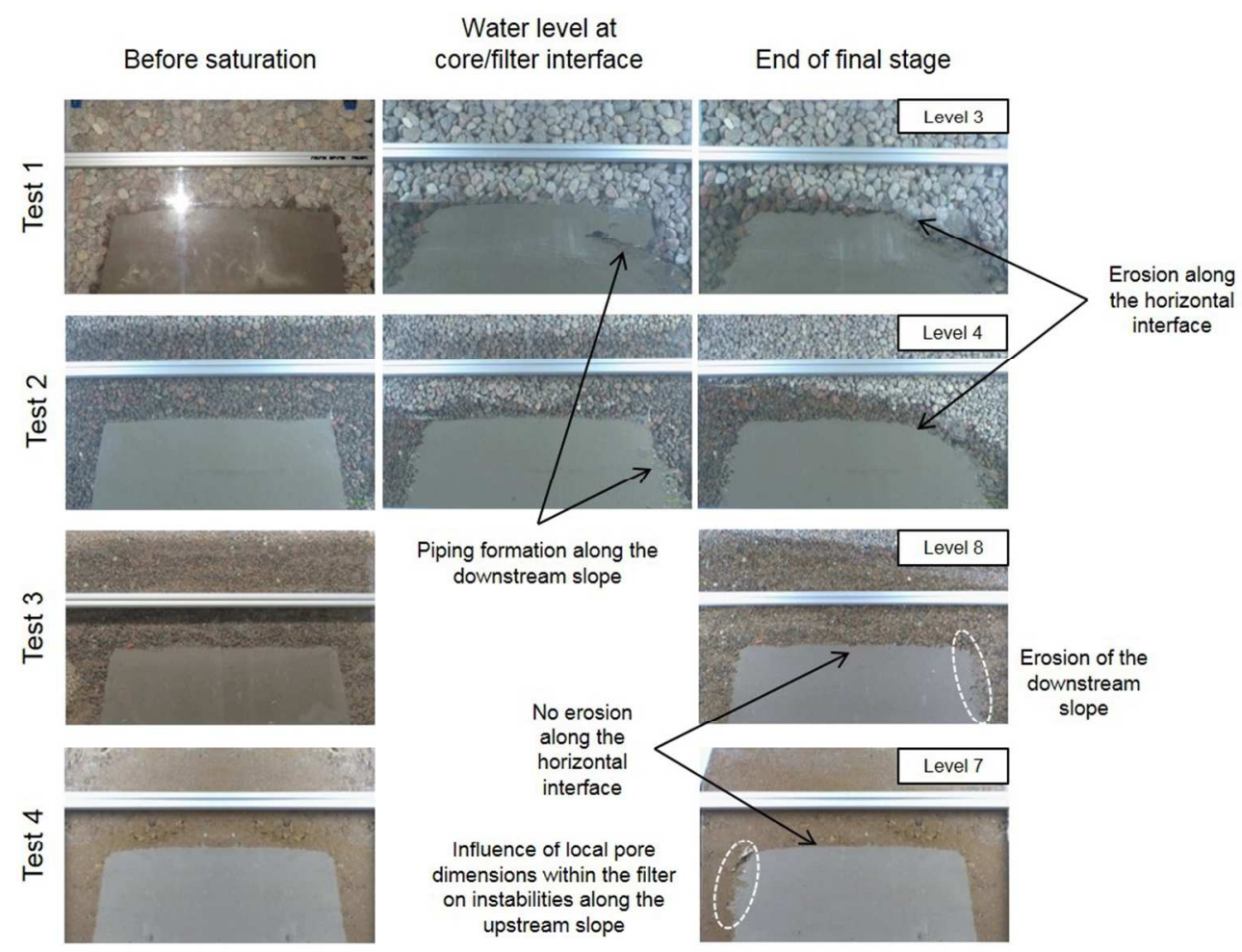

Figure 4: Photographs of Tests 1-4 before saturation, at the end of the stage during which the water level was maintained at the core/filter interface and at the end of each test

$191 \times 146 \mathrm{~mm}(150 \times 150 \mathrm{DPI})$ 


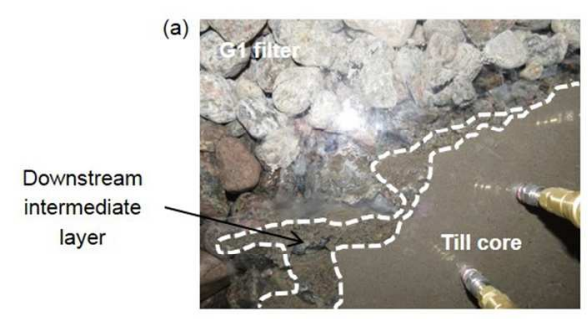

(b)

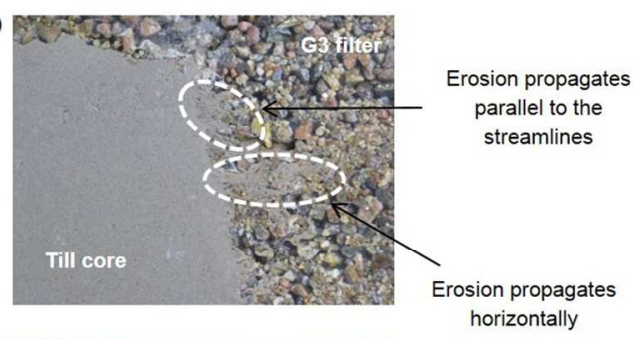

(c)

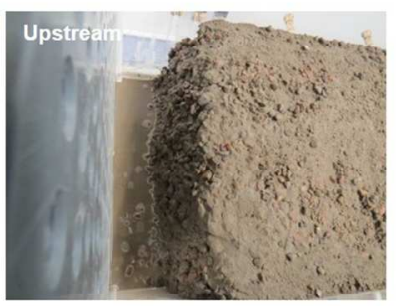

(d)

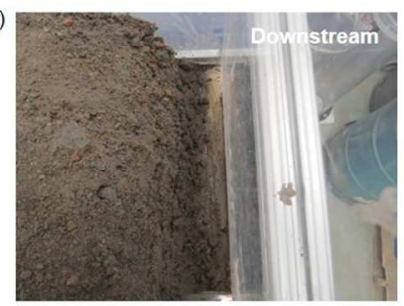

horizontally

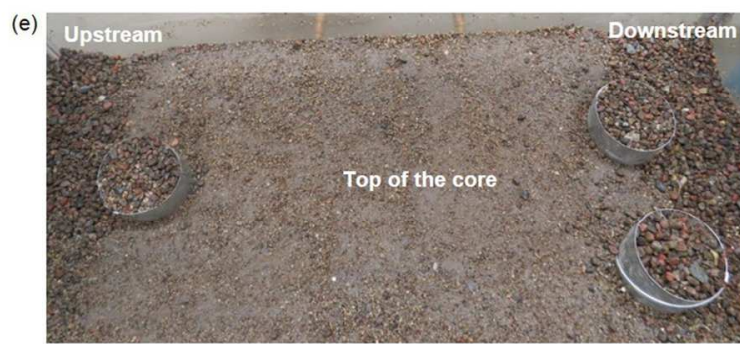

Figure 5: (a) Intermediate filter layer created by paving at the downstream edge of the core for Test 1 (backside of the model); (b) Influence of segregation on migration patterns of eroded particles for Test 3 (frontside of the model); (c) Horizontal and sloped surfaces at the upstream edge (top view) of the core for Test 2; (d) Horizontal and sloped surfaces at the downstream edge (top view) of the core for Test 2; (e) $\mu$ CT sampling locations

$213 \times 162 \mathrm{~mm}(150 \times 150 \mathrm{DPI})$ 

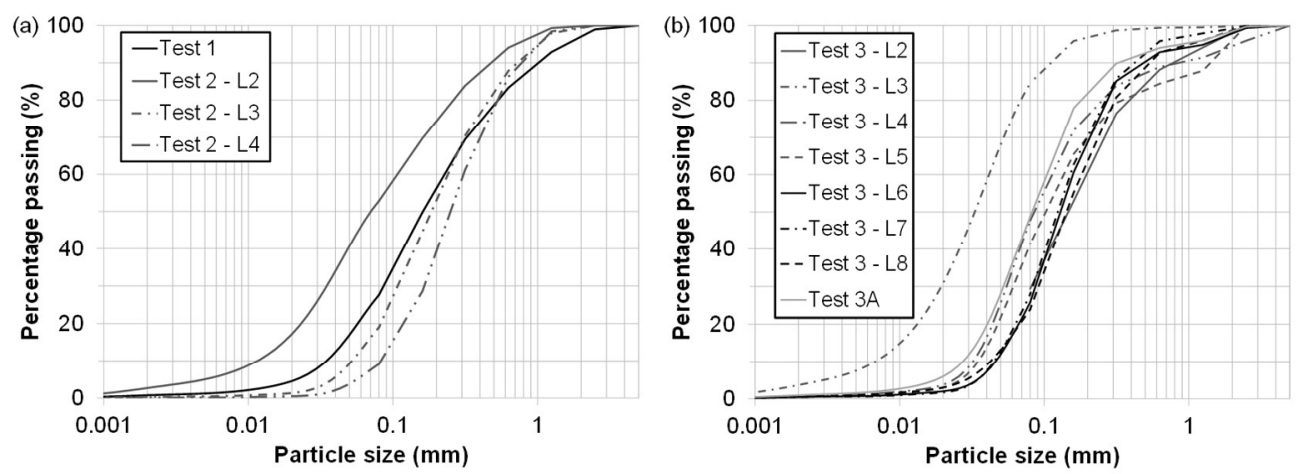

Figure 6: Particle-size distribution of the eroded mass collected: (a) Tests 1-2; (b) Tests 3-3a $284 \times 103 \mathrm{~mm}(150 \times 150 \mathrm{DPI})$ 

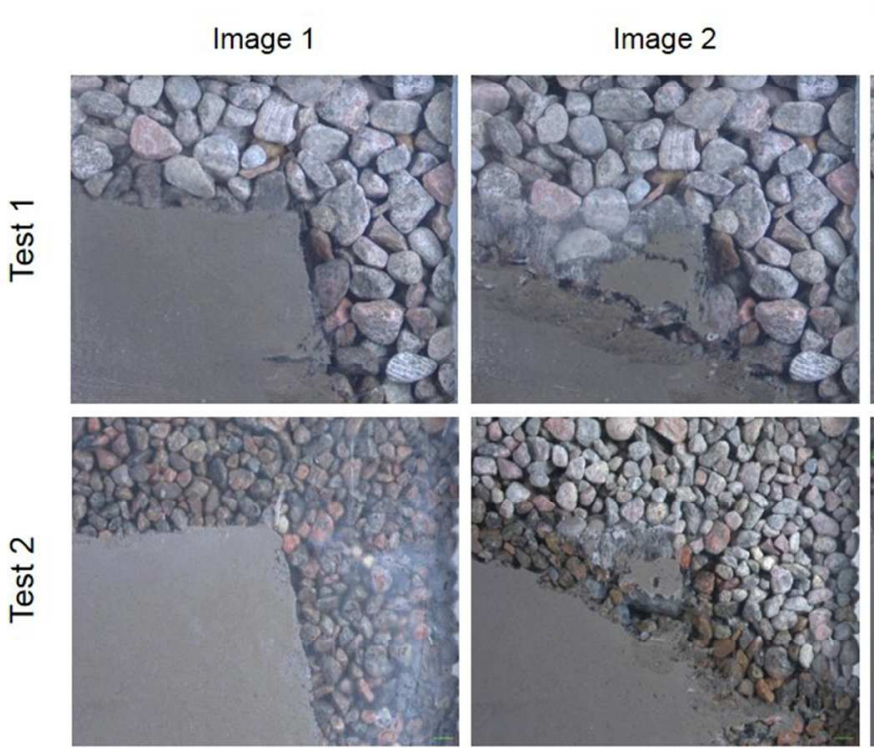

Computed deformation field from Image 1 to Image 2
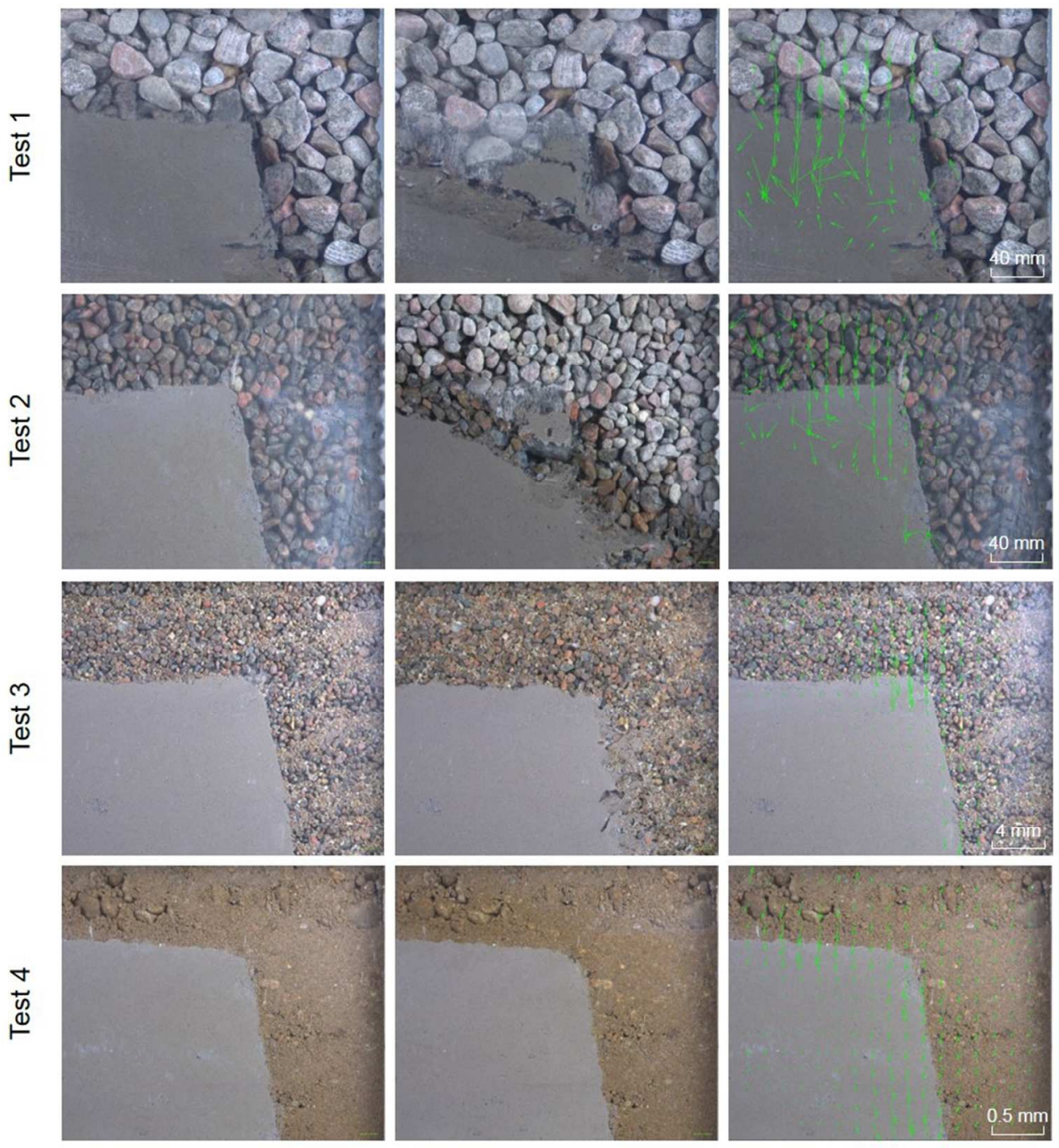

Figure 7: Results from DIC analyses of two recorded images during an erosion stage for Tests 1-4 (vector scales for each test are shown on the figure)

$167 \times 196 \mathrm{~mm}(150 \times 150 \mathrm{DPI})$ 


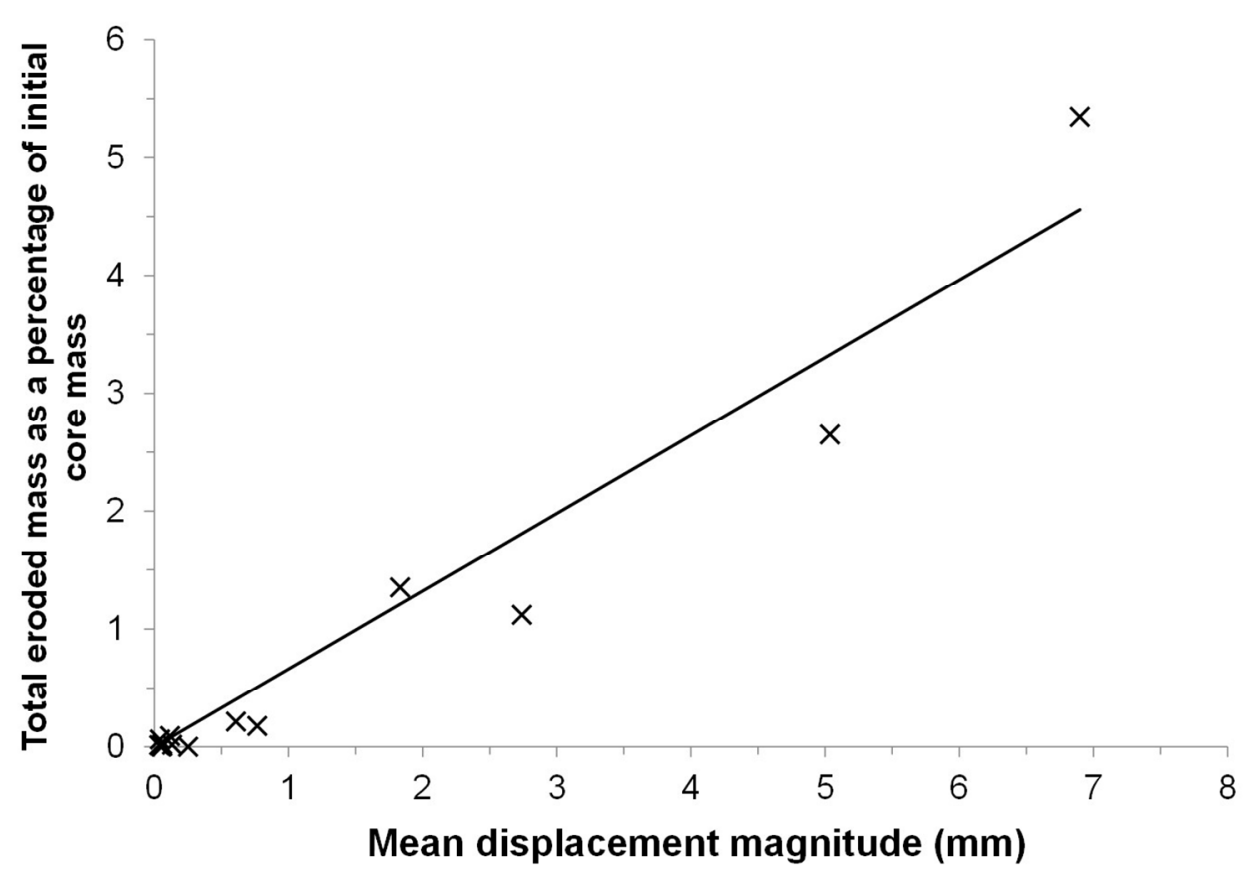

$\%$ mass eroded $=0.6607 \times$ displacement $(m m) \quad R^{2}=0.9414$

Figure 8: Relationship between mean displacement magnitude and total eroded mass as a percentage of initial core mass

$240 \times 174 \mathrm{~mm}(150 \times 150 \mathrm{DPI})$ 


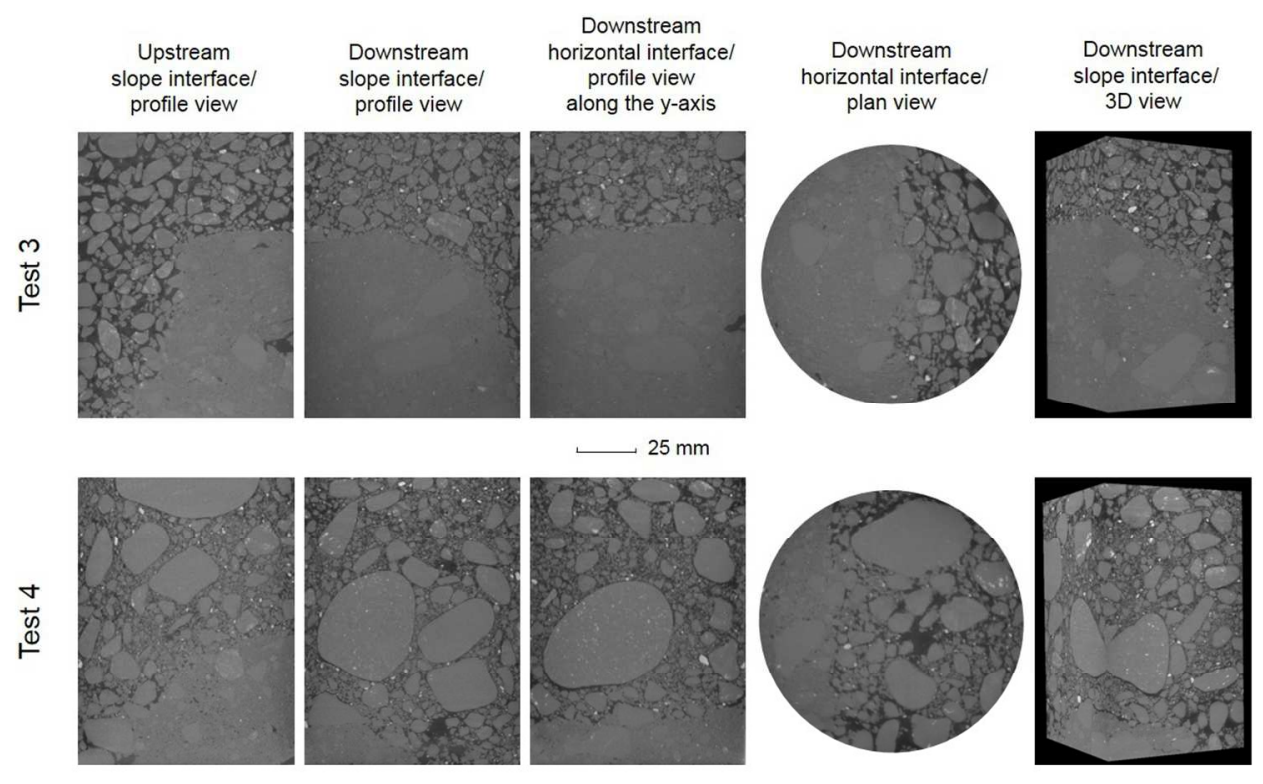

Figure 9: $\mu \mathrm{CT}$ results of downstream and upstream samples for Tests 3 and 4 from different viewpoints $225 \times 139 \mathrm{~mm}(150 \times 150 \mathrm{DPI})$ 
Table 1: Filter criteria, adapted from Fell et al. (2015)

\begin{tabular}{lcc}
\hline Base soil description & $\begin{array}{c}A \\
(\%)\end{array}$ & Filter criteria \\
\hline Fine silts and clays & $>85$ & $D_{15} \leq 9 d_{85}{ }^{* *}$ \\
$\begin{array}{l}\text { Sands, silts, clays and silty } \\
\text { and clayey sands }\end{array}$ & $35-85$ & $D_{15} \leq 0.7 \mathrm{~mm}$ \\
Sands and gravels & $<15$ & $D_{15} \leq 4 d_{85}$ \\
$\begin{array}{l}\text { Silty and clayey sands and } \\
\text { gravels }\end{array}$ & $15-35$ & $D_{15} \leq\left(\frac{35-A}{35-15}\right)\left(4 d_{85}-0.7 \mathrm{~mm}\right)+0.7 \mathrm{~mm}^{* * *}$ \\
\hline
\end{tabular}

For a base soil containing particles larger than the No. $4(4.75 \mathrm{~mm})$ sieve, $A$ is determined from the gradation curve of the base soil which has been adjusted to $100 \%$ passing the No. 4

$(4.75 \mathrm{~mm})$ sieve

** When $9 d_{85}$ is less than $0.2 \mathrm{~mm}$, use $0.2 \mathrm{~mm}$

*** When $4 d_{85}$ is less than $0.7 \mathrm{~mm}$, use $0.7 \mathrm{~mm}$ 
Table 2: Filter criteria validation for each test

\begin{tabular}{cccc}
\hline $\begin{array}{c}\text { Core } \\
\text { material }\end{array}$ & $\begin{array}{c}A \\
(\%)\end{array}$ & & \\
\cline { 1 - 2 } Till & 36.5 & & \\
\hline $\begin{array}{c}\text { Test } \\
\text { number }\end{array}$ & $\begin{array}{c}\text { Filter } \\
\text { material }\end{array}$ & $\begin{array}{c}D_{15} \\
(\mathrm{~mm})\end{array}$ & $\begin{array}{c}\text { Filter criterion } \\
\text { fulfillment }\end{array}$ \\
\hline 1 & $\mathrm{G} 1$ & 22 & No \\
2 & $\mathrm{G} 2$ & 8 & No \\
3 and 3a & G3 & 2.5 & No \\
4 & 2C & 0.5 & Yes \\
\hline
\end{tabular}

9 
11

Table 3: Geotechnical parameters of the materials

\begin{tabular}{ccccccccc}
\hline Material & $\begin{array}{c}\text { Fines } \\
\text { content } \\
(\%)\end{array}$ & $C_{\mathrm{u}}$ & $D_{\mathrm{r}}$ & $e_{\min }$ & $e_{\max }$ & $\begin{array}{c}\rho_{\mathrm{d} \min } \\
\left(\mathrm{kg} / \mathrm{m}^{3}\right)\end{array}$ & $\begin{array}{c}\rho_{\mathrm{d} \max }^{*} \\
\left(\mathrm{~kg} / \mathrm{m}^{3}\right)\end{array}$ & $\begin{array}{c}w_{\text {opt }} \\
(\%)\end{array}$ \\
\hline Till & 31 & 19 & 2.70 & & & & 2,095 & 6.75 \\
$\mathrm{G} 1$ & 0 & 1.5 & 2.67 & & 0.598 & 1,671 & & \\
$\mathrm{G} 2$ & 0 & 1.9 & 2.64 & & 0.576 & 1,675 & & \\
$\mathrm{G} 3$ & 0 & 3.5 & 2.68 & & 0.608 & 1,667 & & \\
2C & 2 & 35 & 2.73 & 0.205 & 0.468 & 1,939 & 2,266 & \\
\hline
\end{tabular}

$12{ }^{*} \rho_{\mathrm{d} \max }$ was evaluated with ASTM (2012) for the till material and with ASTM (2014a) for 2C material

13

14 
Table 4: Parameters derived from the compaction state of the materials for each test

\begin{tabular}{ccccccc}
\hline Test & Material & $\begin{array}{c}\rho_{\mathrm{d}} \\
\left(\mathrm{kg} / \mathrm{m}^{3}\right)\end{array}$ & $\begin{array}{c}w \\
(\%)\end{array}$ & $\begin{array}{c}e \\
(-)\end{array}$ & $\begin{array}{c}R C \\
(\%)\end{array}$ & $\begin{array}{c}I_{\mathrm{d}} \\
(\%)\end{array}$ \\
\hline \multirow{2}{*}{1} & Till & 2,033 & 7.29 & 0.328 & 97.0 & \\
& G1 & 1,671 & & 0.598 & & 0 \\
\hline \multirow{2}{*}{2} & Till & 2,034 & 7.17 & 0.327 & 97.1 & \\
& G2 & 1,675 & & 0.576 & & 0 \\
\hline \multirow{2}{*}{3 and 3a } & Till & 2,046 & 7.12 & 0.320 & 97.7 & \\
& G3 & 1,667 & & 0.608 & & 0 \\
\hline \multirow{2}{*}{4} & Till & 2,038 & 7.18 & 0.325 & 97.3 & \\
& 2C & 2,161 & & 0.268 & & 71.2 \\
\hline
\end{tabular}

16

17 
Table 5: Eroded dry mass for each upstream water level/cycle of each test

19

20

21

22

23

\begin{tabular}{ccccccc}
\hline $\begin{array}{c}\text { Water } \\
\text { level }\end{array}$ & $\begin{array}{c}\text { Test 1 } \\
(\%)\end{array}$ & $\begin{array}{c}\text { Test 2 } \\
(\%)\end{array}$ & $\begin{array}{c}\text { Test 3 } \\
(\%)\end{array}$ & $\begin{array}{c}\text { Test 4 } \\
(\%)\end{array}$ & Cycle & $\begin{array}{c}\text { Test 3a } \\
(\%)\end{array}$ \\
\hline 1 & 0.00 & 0.00 & 0.00 & 0.00 & 1 & $5.64 \times 10^{-3}$ \\
2 & & 0.886 & $9.19 \times 10^{-3}$ & 0.00 & 2 & $2.44 \times 10^{-3}$ \\
3 & $5.35^{*}$ & 1.07 & $4.59 \times 10^{-4}$ & 0.00 & 3 & $2.76 \times 10^{-3}$ \\
4 & & 0.139 & $1.08 \times 10^{-4}$ & 0.00 & 4 & $2.06 \times 10^{-3}$ \\
5 & & & $3.14 \times 10^{-5}$ & 0.00 & 5 & $1.90 \times 10^{-3}$ \\
6 & & & $8.38 \times 10^{-5}$ & 0.00 & 6 & $2.01 \times 10^{-3}$ \\
7 & & & $3.13 \times 10^{-4}$ & 0.00 & & \\
8 & & & $6.79 \times 10^{-5}$ & & & \\
Total $^{* *}$ & 5.35 & 2.65 & $2.14 \times 10^{-1}$ & 0.00 & & $3.64 \times 10^{-2}$ \\
\hline$V^{2}$ & & &
\end{tabular}

Value from this test represents eroded dry mass from levels 2 and 3

** Total mass calculation includes the mass eroded that was also collected in the water tank 